\title{
Pengaruh Konseling pada Ibu Nifas terhadap Pemberian Kolostrum pada Bayi Baru Lahir
}

\author{
Nurma Ika Zuliyanti ${ }^{1}$, Anggieta Febriana ${ }^{2}$ \\ Email: nurmaakbidpurjo@gmail.com¹, anggitafebriana99@gmail.com² \\ D III Akademi Kebidanan Bhakti Putra Bangsa Purworejo, Indonesia \\ Jl. Soekarno Hatta, Boro Kulon, Banyuurip, Purworejo
}

\begin{abstract}
Abstrak
Beberapa faktor yang menyebabkan Ibu tidak memberikan kolostrum bagi bayinya, dan penyebab masih rendahnya praktik pemberian ASI Eksklusif di Kabupaten Kebumen adalah kurangnya tingkat pengetahuan Ibu mengenai manfaat kolostrum bagi bayi, dan beberapa persepsi yang salah mengenai kolostrum, yang dipandang sebagai ASI yang kotor, sehingga tidak patut diberikan pada bayi. Tujuan Untuk mengetahui pengaruh antara konseling pada ibu nifas terhadap pemberian kolostrum pada bayi baru lahir di Klinik Permata Ibu, Kecamatan Prembun Kabupaten Kebumen. Metode yang diguakan Menggunakan desain pra eksperimen dengan rancangan one group pretest posttest. Populasi dalam penelitian sebanyak 34 orang. Analisis dalam penelitian ini yaitu Analisis univariat dan analisis bivariat. Hasil Penelitian: Ibu nifas yang memberikan kolostrum terhadap bayinya sebelum konseling 17 orang $(45,8 \%)$. ibu nifas yang memberikan kolostrum terhadap bayinya setelah konseling sebanyak 28 orang $(90,3 \%)$. Berdasarkan uji normalitas pada pretest dan postest diperoleh $\mathrm{p}<0,05$ meunjukkan data tidak berdistribusi. Positive Rank sebesar 11. Uji Wilcoxon diperiperoleh $\mathrm{Z}$ hitung sebesar $-3,317$ dengan $\mathrm{p}=0,001$.
\end{abstract}

Kata Kunci: konseling ibu nifas; kolostrum.

\begin{abstract}
Some of the factors that cause mothers not to provide colostrum for their babies, and the reasons for the low practice of exclusive breastfeeding in Kebumen Regency are the lack of knowledge of mothers about the benefits of colostrum for babies, and several wrong perceptions about colostrum, which is seen as dirty breast milk, so it is not should be given to babies. Objective To determine the effect of postpartum counseling on colostrum delivery to newborns at Permata Ibu Clinic, Prembun District, Kebumen Regency. The method used was using a pre-experimental design with a one group pretest posttest design. The population in the study was 34 people. The analysis in this research is univariate analysis and bivariate analysis. Results: 17 people (45.8\%) gave colostrum to their babies before counseling. There were 28 postpartum mothers who gave colostrum to their babies after counseling $(90.3 \%)$. Based on the normality test on the pretest and posttest, it was obtained $\mathrm{p}<0.05$, indicating that the data were not distributed. Positive Rank of 11 . Wilcoxon test obtained $\mathrm{Z}$ count of -3.317 with $\mathrm{p}=0.001$.
\end{abstract}

Keywords: postpartum counseling; colostrum. 
Jurnal Kebidanan Harapan Ibu Pekalongan

\section{Pendahuluan}

Air Susu Ibu (ASI) adalah suatu emulsi lemak dalam larutan protein, laktosa, dan garam organik yang di sekresi oleh kedua kelenjar payudara ibu, sebagai makanan utama bagi bayi. ${ }^{1)}$

Pada hari pertama dan kedua, bayi mulai banyak menangis dan ingin menyusu, kondisi ini kerap membuat ibu dan keluarga frustasi, dan tergoda untuk memberikan susu formula sebagai pengganti ASI, padahal jika ASI sedikit dan hanya keluar setetes demi setetes merupakan hal yang wajar di hari pertama sampai ketiga. ASI dalam bentuk kolostrum sudah di produksi sejak kehamilan usia $12 \quad-16$ minggu. Jumlahnya selama 3 hari pertama bervariasi, sekitar 2-20 ml setiap kegiatan menyusui. Memang tidak banyak, tapi itulah yang paling sesuai dengan kebutuhan bayi saat ini. Kolostrum dapat membersihkan usus bayi. BAB bayi ikut serta dalam pembuangan bilirubin, untuk mencegah kadarnya terlalu tinggi dalam tubuh bayi. Bedasarkan Undang - Undang No 36 Tahun 2009 tentang Kesehatan, Peraturan Pemerintah Republik Indonesia Nomor: 33 Tahun 2012 tentang pemberian ASI Eksklusif, Peraturan Bersama Menteri Negara Pemberdayaan Perempuan, Menteri Kesehatan, Nomor: 48/MEN.PP/XII/2008, Nomor: PER.27/MEN/XII/2008, dan Nomor:

177/MENKES/PB/XII/2008 tentang Peningkatan Pemberian ASI selama Waktu Kerja di Tempat Kerja, disebutkan bahwa pemberian ASI Eksklusif pada bayi sampai usia 6 bulan sebesar 30,2 \%, sedangkan target nasional $75 \%$. Bedasarkan dari hasil Riskesdas pada tahun 2018 di Provinsi Jawa Tengah yaitu
92,5 diberikan semua, 3,9 dibuang sebagian, dan 1,4 dibuang semua.

Data

SDKI

menunjukkan presentasi bayi yang menerima ASI Eksklusif di Indonesia yaitu $42 \%$ dan menurun menjadi 30,2\% pada tahun 2013. Pada tahun 2013, cakupan Asi Eksklusif $61,17 \%$ di tahun 2014 turun menjadi 59,3\%, dan angka ini menunjukan bahwa cakupan ASI Eksklusif di kabupaten Kebumen masih di bawah target nasional 80 $\%$. Ada beberapa faktor yang menyebabkan Ibu tidak memberikan kolostrum bagi bayinya, dan penyebab masih rendahnya praktik pemberian ASI Eksklusif di Kabupaten Kebumen adalah kurangnya tingkat pengetahuan Ibu mengenai manfaat kolostrum bagi bayi, dan beberapa persepsi yang salah mengenai kolostrum, yang dipandang sebagai ASI yang kotor, sehingga tidak patut diberikan pada bayi. Kandungan kolostrum yang tidak diketahui ibu sehingga banyak ibu di masa setelah persalinan tidak memberikan kolostrum pada bayi baru lahir karena pengetahuan tentang kandungan kolostrum itu tidak ada. ${ }^{2)}$

Berdasarkan studi pendahuluan yang dilakukan peneliti pada bulan November 2019 di Klinik Permata Ibu Kebumen, dari hasil wawancara dengan 8 ibu nifas yang bersalin secara normal, dimana dari jumlah tersebut terdapat 5 ibu nifas yang belum mengetahui tentang manfaat kolostrum dan tidak memberikan kolostrumnya secara penuh dengan alasan ASI pada hari pertama belum lancar dan masih keluar sedikitsedikit, sehingga disambung dengan susu formula, sedangkan 3 orang ibu nifas sudah mengetahui informasi kolostrum yaitu pada saat bidan memberikan konseling, dan 
Jurnal Kebidanan Harapan Ibu Pekalongan

ibu telah memberikan kolostrumnya secara penuh untuk bayinya, meskipun kolostrum baru keluar sedikit pada hari pertama postpartum. Tujuan Penelitian: Untuk mengetahui pengaruh antara konseling pada ibu nifas terhadap pemberian kolostrum pada bayi baru lahir di Klinik Permata Ibu, Kecamatan Prembun Kabupaten Kebumen

\section{Metode Penelitian}

Metode penelitian ini praeksperimen dengan rancangan one group pretest-posttest. Populasi dalam penelitian ini adalah seluruh ibu nifas di Klinik Permata Ibu pada bulan Februari - April 2020 sebanyak 34 ibu nifas. Pengambilan sampel dengan teknik Accidental Sampling didapatkan sampel sejumlah 31 responden. Penelitian terdiri dari 2 variabel, variabel independen konseling kolostrum, variabel dependen pemberian kolostrum setelah diberi konseling. Instrumen penelitian dengan ceklist. Data yang digunakan data primer berupa observasi pada ibu nifas. Uji statistik menggunakan Uji Wilcoxon Rank Test. ${ }^{6}$

\section{Hasil dan Pembahasan}

\section{Hasil Penenelitian}

Tabel 1. Distribusi Frekuensi Pemberian Kolostrum pada Bayi Baru Lahir sebelum Konseling

\begin{tabular}{clcc}
\hline No & $\begin{array}{l}\text { Pemberian } \\
\text { Kolustrum }\end{array}$ & F & $\%$ \\
\hline 1. & Diberikan & 17 & 54,8 \\
\hline 2. & $\begin{array}{l}\text { Tidak } \\
\text { diberikan }\end{array}$ & 15 & 45,2 \\
\hline Jumlah & 31 & 100,0 & \\
\hline
\end{tabular}

Berdasarkan tabel 1 diketahui ibu nifas yang memberikan kolostrum terhadap bayinya sebelum konseling sebanyak 17 orang $(54,8 \%)$ dan yang tidak memberikan kolostrum 15 orang $(45,2 \%)$.

\begin{tabular}{|c|c|c|c|}
\hline \multicolumn{4}{|c|}{$\begin{array}{ccc}\text { Tabel } 2 . \quad \text { Distribusi } & \text { Frekuensi } \\
\text { Pemberian Kolostrum pada Bayi } \\
\text { Baru Lahir setelah Konseling }\end{array}$} \\
\hline No & $\begin{array}{l}\text { Pemberian } \\
\text { Kolostrum }\end{array}$ & $\mathbf{F}$ & $\%$ \\
\hline 1. & Diberikan & 28 & 90,3 \\
\hline 2. & $\begin{array}{l}\text { Tidak } \\
\text { diberikan }\end{array}$ & 3 & 9,7 \\
\hline Jumlah & 31 & 100,0 & \\
\hline
\end{tabular}

Berdasarkan tabel 2 diketahui ibu nifas yang memberikan kolostrum terhadap bayinya setelah konseling sebanyak 28 orang $(90,3 \%)$ dan yang tidak memberikan kolostrum 3 orang $(9,7 \%)$.

Tabel 3 Hasil Uji Normalitas

\section{Tests of \\ Normality}

\begin{tabular}{|c|c|c|}
\hline & $\begin{array}{l}\text { Kolmogorov- } \\
\text { Smirnov }^{a} \\
\end{array}$ & $\begin{array}{c}\text { Shapiro- } \\
\text { Wilk }\end{array}$ \\
\hline & Statistic & Statistic $d f$ Sig. \\
\hline Pretest & .36231 .000 & .63531 .000 \\
\hline Postest & .53031 .000 & .34031 .000 \\
\hline $\begin{array}{l}\text { Lilliefors } \\
\text { a.Significanc } \\
\text { e Correction }\end{array}$ & & \\
\hline
\end{tabular}

Berdasarkan uji normalitas pada pretest dan postest diperoleh $\mathrm{p}<0,05$ menunjukkan data tidak berdistribusi normal. Hal ini menunjukkan pengujian hipotesis menggunakan uji Wilcoxon Rank Test. 
Jurnal Kebidanan Harapan Ibu Pekalongan

Tabel 4 Hasil Statistik Uji Wilcoxon Rank Test

\begin{tabular}{lr}
\hline \multicolumn{1}{c}{ Test Statistics } \\
\hline$Z$ & Postest- Pretest \\
\hline Asymp. Sig. (2-tailed) & $-3.317^{b}$ \\
\hline a. Wilcoxon Signed & .001 \\
Ranks Test \\
\hline b. Based on negative \\
ranks. \\
\hline
\end{tabular}

Berdasarkan uji Wilcoxon diperoleh $\mathrm{Z}$ hitungsebesar $-3,317$ dengan $\mathrm{p}=0,001$. Karena $\mathrm{p}<0,05$ maka Ho ditolak da $\mathrm{Ha}$ diterima artinya ada pengaruh konseling terhadap pemberian kolostrum pada Bayi Baru Lahir di Klinik Permata Ibu, Kecamatan Prembun, Kabupaten Kebumen.

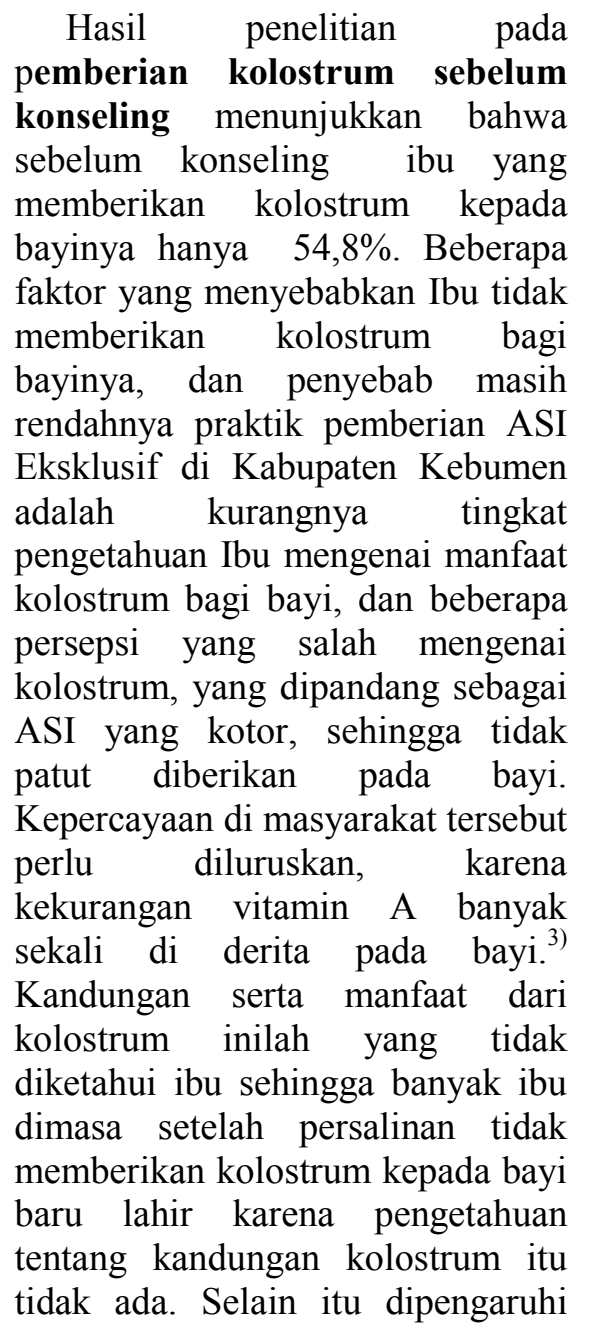

pengaruhi pengetahuan masalah kolustrum sering terjadi pada ibu primipara. Oleh karena itu ibu perlu diberikan penjelasan mengenai perawatan payudara, cara menyusui yang benar dan hal-hal yang erat hubungan dengan menyusui .4)

Sedangkan data ibu nifas yang memberikan kolostrum terhadap bayinya setelah konseling sebanyak 28 orang $(90,3 \%)$ dan yang tidak memberikan kolostrum 3 orang $(9,7 \%)$. Salah satu upaya untuk melakukan promosi agar ibu nifas memberikan kolostrum adalah menggunakan konseling. konseling merupakan serangkaian kegiatan paling pokok dari bimbingan dalam usaha membantu konseli/klien secara tatap muka langsung dengan tujuan agar klien dapat mengambil tanggung jawab sendiri terhadap berbagai persoalan atau masalah khusus sehingga masalah klien dapat teratasi. ${ }^{5}$ Konseling yang diberikan meliputi pengertian kolostrum, manfaat kolostrum, reflek yang berpertan dan dampak jika bayi tidak diberi kolostrum. Tujuan pemberian konseling dalam penelitian ini adalah menambah informasi kepada ibu nifas akan pentingnya kolostrum bagi bayi, sehingga dapat memotivasi ibu nifas untuk memberikan kolostrum bagi bayinya.

Konseling yang diberikan penulis cukup berhasil. Ini ditunjukkan pda postest jumlah ibu nifas yang memberikan kolostrum meningkat dari 17 menjadi 28 orang. Pengujian hipotesis penelitian mermperkuat hasilnya penelitian bahwa ada pengaruh konseling terhadap pemberian kolostrum pada Bayi Baru Lahir di Klinik Permata Ibu, Kecamatan Prembun, Kabupaten Kebumen.

Analisis data menggunakan uji Wilcoxon Rank Test diperoleh 
Jurnal Kebidanan Harapan Ibu Pekalongan

Positive Rank sebesar 11 artinya pada postest nifas yang sebelum konseling tidak memberikan kolostrum dan setelah konseling memberikan kolostrum kepada bayinya sebanyak 11 orang. Berdasarkan uji Wilcoxon diperoleh $Z$ hitung sebesar $-3,317$ dengan $p=0,001$. Karena $p<0,05$ maka Ho ditolak da Ha diterima artinya ada pengaruh konseling terhadap pemberian kolostrum pada Bayi Baru Lahir di Klinik Permata Ibu, Kecamatan Prembun, Kabupaten Kebumen.

Hasil ini sejalan dengan penelitian Ambarwati,R.(2013) tentang Pengaruh Konseling Laktasi Intensif terhadap Pemberian ASI Eksklusif pada Bayi di Puskesmas Padangsari, Semarang menunjukkan Pelaksanaan pemberian ASI Eksklusif lebih tinggi pada Ibu yang mendapatkan konseling laktasi (39,5\%), dibandingkan Ibu yang tidak mendapatkan konseling $(19,6 \%)$

\section{Kesimpulan}

Pemberian kolostrum pada bayi baru lahir di Klinik Permata Ibu, Kecamatan Prembun, Kabupaten Kebumen sebelum konseling $54,8 \%$, sedangkan setelah konseling $90,3 \%$. Ada pengaruh konseling terhadap pemberian kolostrum pada Bayi Baru Lahir di Klinik Permata Ibu, Kecamatan Prembun, Kabupaten Kebumen dengan $Z$ hitung $=-3,317$ dan $\mathrm{p}=0,001$.

\section{Daftar Pustaka}

[1] Sutanto, Andina Vita. Asuhan Kebidanan Nifas dan Menyusui. Yogyajarta : Pustaka Baru Press. Dkk (et al), 2018.

[2] Ambarwati, R. Pengaruh Konseling Laktasi Intensif Terhadap Pemberian Air Susu Ibu (ASI) Eksklusif Sampai 3 Bulan. Jurna Gizi Indonesia, vol.2, 15-23, 2013.

[3] Proverawati. A. Kapita Selekti ASI dan Menyusui. Yogyakarta: Nuha Medika, 2010.

[4] Bahiyatun. Buku Ajar Asuhan Kebidanan Normal. Jakarta: EGC, 2010.

[5] Prayitno dan Amti. Dasar Dasar Bimbingan dan Konseling. Jakarta: Pusat Perbukuan, 2014.

[6] Notoatdmodjo, S. Metodologi Penelitian Kesehatan. Jakarta: Rineka Cipta, 2014.

[7] Purwanti, Hubertin Sri. Konsep Penerapan ASI Eksklusif : Buku saku untuk bidan, Jakarta: EGC, 2011. 